\title{
Poverty reduction through women employment in farms and rice mills in an area of Dinajpur district
}

\author{
M. S. Rahman ${ }^{1}$ and M. R. Hasan ${ }^{2}$ \\ ${ }^{1}$ Department of Agricultural Economics, Bangladesh Agricultural University, Mymensingh and ${ }^{2}$ Department of \\ Economics, Hajee Mohammad Danesh Science and Technology University, Dinajpur, Email: saidurbau@yahoo.com
}

\begin{abstract}
The study was undertaken to examine the socio-economic profiles of women participated in farms and rice mills activities; to examine contribution of women to household income which reducing their poverty; to identify the factors influencing the level of family income in farms and rice mills labourers; and to identify the problems and constraints of farms and rice mills. Bochagonj Upazila of Dinajpur district was selected purposively for the study considering the availability of large number of farm and rice mill labourers. Sixty samples of each category have been selected by random sampling procedure and primary data were collected by direct interview through a pre-tested survey schedule. The educational status, land holding and other household assets position were improved due to the women's contribution to overall family income. Patterns of family expenditure remained same before and after the women involvement in farm and rice mill works but increased over time that indicated some significant changes in the level of poverty of the households. Age of the respondents, family size, land holding, number of earning members and respondents' income contributed significantly to the variability of income and employment. Major problems were nature of the work and the variation in the salary level between male and female labourers. Finally, women contributed a small amount but a significant proportion of their family income and the socioeconomic status of the women farm and rice mill labourers should be improved through direct participation in income generating activities by reducing the male and female discriminations.
\end{abstract}

Keywords: Poverty, Women employment, Farm, Rice mills, Income

\section{Introduction}

Bangladesh economy is basically dependent on rice base agriculture which occupies 10.58 million ha of land and produces 27.30 million tones of rice (BBS, 2007). But the status of rice processing pattern did not change. Rice processing includes parboiling (soaking and steaming), drying and milling in order to obtain milled rice. More than $80 \%$ of rice is processed in villages and less than $20 \%$ rice is processed in commercial rice mills. Rural women are playing significant role in rice processing activities. Women in agriculture are a popular area of study and now it is well accepted that women are the initiators of agricultural activities in the history of mankind. Women carry a heavy load to convert paddy to edible grain by threshing, soaking, parboiling, drying, husking, winnowing and preserving seed. Milling is the final rice post-harvest processing. It includes pre-cleaning, husking, bran removal, cleaning and grading. Akter (1995), Salauddin (1980) and Harriss (1978) reported that about 65\% of paddy is milled by traditional methods and $90 \%$ of rice produced in Bangladesh is processed by women in their homesteads and in small custom mills located in the rural areas. The traditional means of post-harvest operations are very slow and hazardous to health, particularly for women. There is a lack of knowledge and awareness regarding safety of labourers in the rice mills. The environmental impact of rice processing system requires thorough investigation for improvement of working environment and health status of mill labourers.

In rural Bangladesh, poverty alleviation is hardly achieved unless women are encouraged to participate in the income generating activities outside their homestead. They are facing obstacles and oppressions due to various conservative people. Women who are struggling hard to manage their livelihood and trying to overcome poverty generally do not get any support from the influential people of the society (Begum, 2005). In Bangladesh the movement for women's emancipation is going on as a part of the process of social changes and not as a revolutionary movement (Haq, 1981). However, studies on women participation in farming and rice processing system in rice mill are very limited in number. In this study emphasis has been placed to explore the hindrances to women's development, the ways the women 
labourers are used in agrarian economy to reduce poverty that can bring a change for rural development. Considering the facts, the following objectives were taken for the present study, to examine the socioeconomic profiles of women participated in farms and rice mills activities; to examine the contribution of women to household income that reduces their poverty; to identify the factors influencing the level of family income in farms and rice- mills labourers; and to identify the problems and opportunities of farms and rice-parboiling mills.

\section{Materials and Methods}

To achieve the objectives of the present study, a preliminary survey had been conducted in Bochagonj Upazila of Dinajpur district to understand the broad socioeconomic characteristics of the area in October to December, 2009. On the basis of preliminary information and considering the objectives, time, availability of fund, manpower and availability of mill proprietors, mill women labourer and farmwomen labourer were selected randomly. The sample frame was prepared by classifying the households according to their farm and rice parboiling mill activities. Sixty labourers of rice-mill and 60 farm women labourer were selected randomly from a list of total number.

Mostly tabular analyses were done for the study. To find out the factors affecting income generating activities (Gujarati, 1998) of the respondents' households, a log-linear regression model was used as follows :

$$
\begin{aligned}
& \ln Y=\operatorname{lna}+b_{1} \ln X_{1}+b_{2} \ln X_{2}+b_{3} \ln X_{3}+b_{4} \ln X_{4}+b_{5} \ln X_{5}+u i \\
& \text { Where, } \\
& Y=\text { Average annual income per household (Tk/yr) } \\
& X_{1}=\text { Age of the respondent (Year) } \\
& X_{2}=\text { Family size (Number of family members) } \\
& X_{3}=\text { Land holding (Decimal) } \\
& X_{4}=\text { Number of earning members per household (Number) } \\
& X_{5}=\text { Respondents' money income (Tk/yr) } \\
& \text { In = Natural logarithm } \\
& \text { ui = Stochastic errors }
\end{aligned}
$$

\section{Results and Discussion}

\section{Socio-economic profiles of the selected respondents}

Age distribution of the respondents: The highest percentage of farm and rice mill labourers were from the age group between 20 to 30 years ( 43.33 and 41.67\%, respectively) and their average age were 27 years. The lowest percentages of farm and rice mill labourers came from the age group between 50 to 60 and 60 and above years (3.33 and 1.66\%, respectively) and their average age were 54 and 62.5 years, respectively. The average ages of the selected respondents were 34 to 36 years (Table 1).

Table 1. Age distribution of the respondents

\begin{tabular}{|l|c|c|c|c|}
\hline \multirow{2}{*}{ Age group (Years) } & \multicolumn{2}{|c|}{ Farm labourer } & \multicolumn{2}{c|}{ Rice-mill labourer } \\
\cline { 2 - 5 } & No. of labourer & $\begin{array}{c}\text { Average age } \\
\text { (Year) }\end{array}$ & $\begin{array}{c}\text { Average of labourer } \\
\text { (Year) }\end{array}$ \\
\hline 20 to 30 & $26(43.33)$ & 27.0 & $25(41.67)$ & 26.3 \\
\hline 30 to 40 & $21(35.0)$ & 35.2 & $18(30.0)$ & 37.0 \\
\hline 40 to 50 & $11(18.34)$ & 46.5 & $15(25.0)$ & 46.0 \\
\hline 50 to 60 & $2(3.33)$ & 54.0 & $1(1.66)$ & 59.0 \\
\hline Above 60 & - & - & $1(1.67)$ & 62.5 \\
\hline Total & $60(100.0)$ & 34.35 & $60(100.0)$ & 35.77 \\
\hline
\end{tabular}

Source: Field Survey, 2010

Note: Figures in the parentheses indicate percentages. 
Education of the respondents: Table 2 revealed the educational status of the sample labourers. It was evident that, 96.67 percent farm labourers and 85 percent rice mill labourers were illiterate. Only 1.67 percent farm labourers were literate up to primary and secondary level. No secondary and above level of education were found for the rice mill labourer. Only 15 percent rice mill labourers were literate up to primary level of education.

Table 2. Educational status of the sample labourers

\begin{tabular}{|l|c|c|c|c|c|c|}
\hline \multirow{2}{*}{ Level of education } & \multicolumn{2}{|c|}{ Farm labourer } & \multicolumn{2}{c|}{ Rice mill labourer } & \multicolumn{2}{c|}{ All } \\
\cline { 2 - 7 } & Number & Percent & Number & Percent & Number & Percent \\
\hline Illiterate & 58 & 96.67 & 51 & 85.0 & 109 & 90.83 \\
\hline Up to primary & 1 & 1.67 & 9 & 15.0 & 10 & 8.34 \\
\hline Up to secondary & 1 & 1.66 & - & - & 1 & 0.83 \\
\hline Total & 60 & 100 & 60 & 100 & 120 & 100 \\
\hline
\end{tabular}

Source: Field Survey, 2010

Occupation of the respondents: Wage labor was the main source of employment for the respondents in the study area. Some labourers also participated in housework, petty business, etc. Table 3 showed the occupation structure of the sample labourers. Among 60 farm labourers, only 36 were engaged in different activities before engaging as the farm labourer. The highest percent of farm labourers (80.55 and 81.67 percent) were employed in agricultural wage labor, respectively for before and after engaging as agricultural wage labourer. Among 60 rice mill labourers, only 31 were engaged in different activities before engaging as the rice parboiling work. The highest percent of rice mill labourers (90.32 and 66.67 percent) were employed in rice parboiling activities, respectively for before and after engaging as rice millwork.

Table 3. Occupational status of the sample labourers

\begin{tabular}{|l|c|c|c|c|c|c|}
\hline \multirow{2}{*}{ Occupation } & \multicolumn{2}{c|}{ Farm labourer (No.) } & \multicolumn{2}{c|}{ Rice-mill labourer (No.) } & \multicolumn{2}{c|}{ All (No.) } \\
\cline { 2 - 7 } & Before & After & Before & After & Before & After \\
\hline Only wage labourer & $29(80.55)$ & $49(81.67)$ & $28(90.32)$ & $40(66.67)$ & $57(85.07)$ & $89(74.17)$ \\
\hline Wage labourer + House maid & - & - & $3(9.68)$ & $8(13.33)$ & $3(4.48)$ & $8(6.67)$ \\
\hline Wage labourer + Petty business & $1(2.78)$ & - & - & $3(5.0)$ & $1(1.49)$ & $3(2.50)$ \\
\hline Wage labourer + Others & $6(16.67)$ & $11(18.33)$ & - & $9(15.0)$ & $6(8.96)$ & $20(16.66)$ \\
\hline Total & $36(100)$ & $60(100)$ & $31(100)$ & $60(100)$ & $67(100)$ & $120(100)$ \\
\hline
\end{tabular}

Source: Field Survey, 2010

Note: Figures in the parentheses indicate percentages.

Land holding of the respondents: Table 4 showed that, farm labourers possessed on an average 6.23 decimal of land before engaging in farm activities and 15.65 decimal of land after engaging in farm activities. Rice mill labourers possessed on an average 1.77 decimal of land before engaging in the rice parboiling activities and 2.84 decimal of land after engaging as the rice parboiling activities. It implied that, farm labourers used their income to increase their land resources as well as to enhance productivity by using the land in various agricultural activities than the rice mill labourers.

\section{Average family size and distribution of family members by education}

Family size is defined as the total number of persons living together and taking meals from the same kitchen under the administration of the same head of the family. The average family sizes of the farm labourer and rice mill labourer were 4.39 and 4.36 persons respectively which were slightly lower than that of country average, i.e., 4.9 (BBS, 2008). The farm labourers were illiterate (59.18 percent male and 66.06 percent female). Thirty one percent farm male labourer has education up to primary level while 25.79 percent female labourer has primary education. Less than 10 percent male and female labourers have education at secondary level. Fifty three and 65 percent rice-mill labourers were illiterate. Like farm labourers, the same trend of education level were found in case of primary and secondary level (Table 5). 
Table 4. Average land holding of the respondents (in decimal)

\begin{tabular}{|l|c|c|c|c|}
\hline \multirow{2}{*}{ Categories of land area } & \multicolumn{4}{|c|}{ Respondent's category } \\
\cline { 2 - 5 } & \multicolumn{2}{|c|}{ Farm labourer } & Before mill labourer \\
\cline { 2 - 5 } & Before & After & 1.10 & After \\
\hline Homestead area & 3.50 & 5.37 & - & - \\
\hline Cultivable land (a+b+c-d-e) & & & - & - \\
a) Own cultivable & 1.90 & 1.19 & 0.67 & 0.85 \\
b) Rented in & 0.83 & 9.09 & - & - \\
c) Leased in & - & - & - & - \\
d) Rented out & - & - & - & - \\
e) Leased out & - & - & 1.77 & 2.84 \\
\hline Pond & - & 15.65 & \\
\hline Total & 6.23 & &
\end{tabular}

Source: Field Survey, 2010

Table 5. Average family size and distribution of family members by education

\begin{tabular}{|l|c|c|c|c|}
\hline \multirow{2}{*}{\multicolumn{1}{|c|}{ Educational status }} & \multicolumn{2}{c|}{ Farm labourer } & \multicolumn{2}{c|}{ Rice-mill labourer } \\
\cline { 2 - 5 } & Male (No.) & Female (No.) & Male (No.) & Female (No.) \\
\hline Illiterate & $1.29(59.18)$ & $1.46(66.06)$ & $1.13(53.05)$ & $1.44(64.58)$ \\
\hline Upto primary & $0.68(31.19)$ & $0.57(25.79)$ & $0.78(36.62)$ & $0.60(26.90)$ \\
\hline Upto secondary & $0.21(9.63)$ & $0.18(8.15)$ & $0.22(10.33)$ & $0.19(8.52)$ \\
\hline All types & $2.18(100)$ & $2.21(100)$ & $2.13(100)$ & $2.23(100)$ \\
\hline Average family size (No.) & \multicolumn{2}{|c|}{4.39} & \multicolumn{3}{c|}{4.36} \\
\hline
\end{tabular}

Source: Field Survey, 2010

Note: Figures in the parentheses indicate percentages

Assets position of the households: Table 6 represents households assets structure and their value. These household assets include livestock, poultry, television, furniture, farm implements, rickshaw/van, tailoring shop, etc. It was found that both the farm labourers and rice mill labourers possessed cow, goat, poultry, katcha house, some sorts of furniture, tea stall and tailoring shop before engaging as farm and rice mill labourers. Their assets were slightly increased in value and number after engaging as farm and rice mill labourers.

Table 6. Assets position of the sample households

\begin{tabular}{|c|c|c|c|c|c|c|c|c|}
\hline \multirow{4}{*}{ Types of assets } & \multicolumn{8}{|c|}{ Household category } \\
\hline & \multicolumn{4}{|c|}{ Farm labourer } & \multicolumn{4}{|c|}{ Rice mill labourer } \\
\hline & \multicolumn{2}{|c|}{ Before } & \multicolumn{2}{|c|}{ After } & \multicolumn{2}{|c|}{ Before } & \multicolumn{2}{|c|}{ After } \\
\hline & $\begin{array}{c}\text { Quantity/ } \\
\text { No. }\end{array}$ & $\begin{array}{l}\text { Value } \\
\text { (Tk) }\end{array}$ & $\begin{array}{c}\text { Quantity/ } \\
\text { No. }\end{array}$ & $\begin{array}{c}\text { Value } \\
(\mathrm{Tk})\end{array}$ & $\begin{array}{c}\text { Quantity/ } \\
\text { No. }\end{array}$ & $\begin{array}{c}\text { Value } \\
(\mathrm{Tk})\end{array}$ & $\begin{array}{c}\text { Quantity/ } \\
\text { No. }\end{array}$ & $\begin{array}{c}\text { Value } \\
(\mathrm{Tk})\end{array}$ \\
\hline Livestock: & & & & & & & & \\
\hline Cow & 0.64 & 5728.6 & 1.19 & 10535.71 & 0.15 & 1133.30 & 0.28 & 2700.00 \\
\hline Sheep & - & - & - & - & 0.10 & 200.00 & 0.10 & 221.00 \\
\hline Goat & 0.27 & 275.0 & 0.68 & 960.71 & 0.35 & 308.30 & 0.23 & 283.33 \\
\hline Poultry bird & 0.57 & 71.43 & 1.36 & 167.86 & 0.97 & 105.00 & 1.45 & 181.66 \\
\hline Farm Implements: & & & & & & & & \\
\hline Shallow Tubewell & 0.018 & 200.0 & 0.036 & 339.29 & - & - & - & - \\
\hline Husking machine & - & - & - & - & - & - & - & - \\
\hline Housing assets: & & & & & & & & \\
\hline Katcha & 0.95 & 6196.0 & 1.37 & 10295.0 & 0.35 & 1758.33 & 1.26 & 7591.67 \\
\hline Furniture & 1.0 & 421.43 & 1.95 & 815.0 & 0.70 & 710.00 & 2.50 & 2016.66 \\
\hline Television & - & - & 0.089 & 267.85 & 0.018 & 83.33 & 0.10 & 583.33 \\
\hline Others: & & & & & & & & \\
\hline Rickshaw/van & - & - & 0.036 & 142.86 & 0.03 & 133.33 & 0.06 & 233.00 \\
\hline Tailoring shop & - & - & - & - & - & - & - & - \\
\hline Tea stall & 0.018 & 26.78 & 0.036 & 78.57 & - & - & - & - \\
\hline Grocery shop & - & - & 0.018 & 35.71 & - & - & 0.033 & 183.33 \\
\hline Total (Tk) & - & 12919.24 & - & 23638.14 & - & 4431.59 & - & 12213.31 \\
\hline
\end{tabular}

Source: Field Survey, 2010 


\section{Contribution of women to household income in reducing poverty}

Sources and patterns of income and employment: Fig. 1 represents the sources and patterns of income and employment of the farm and rice mill labourers. Source of income item is represented along $\mathrm{X}$-axis and $\mathrm{Y}$-axis represents the number of working days, income and percent of income of the farm and rice mill labourers.

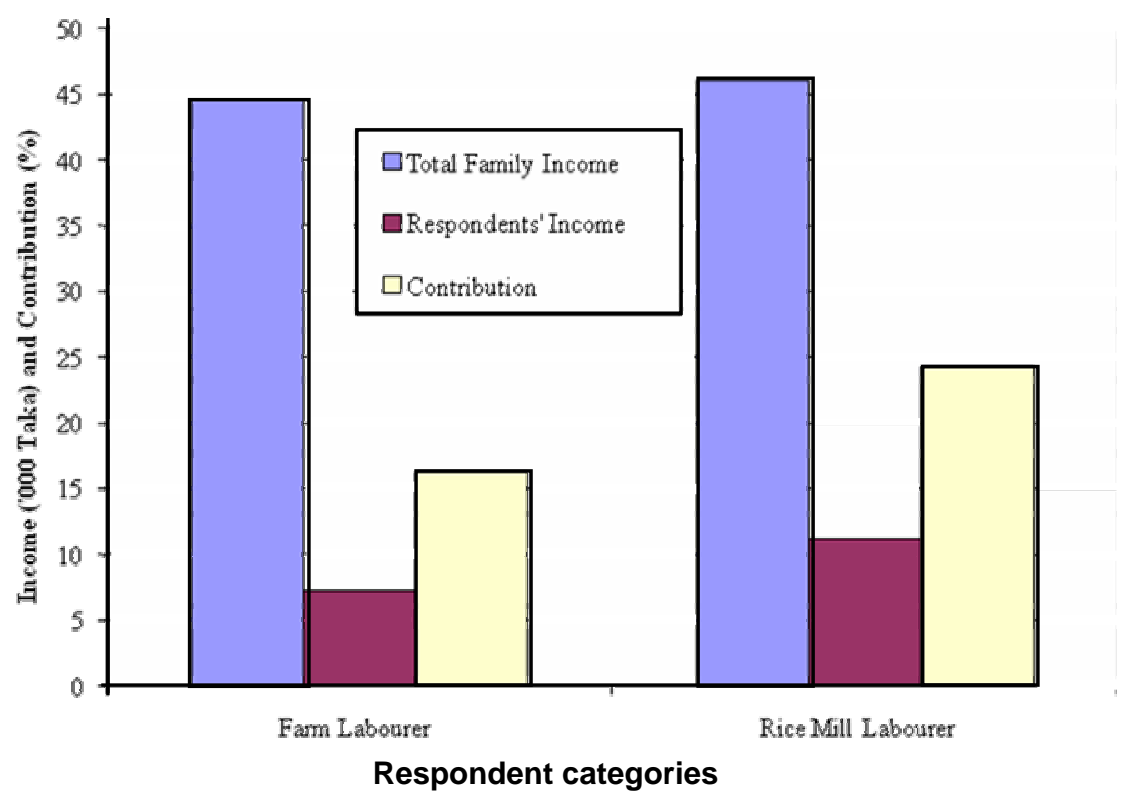

Fig. 1. Contribution of women to the overall household income

The average annual days employed by the farm labourers were 159.29 days in which 120.45 days as agricultural wage labourer and rest of the days as day labourer. About eighty six percent income earned by the farm labourers were from agricultural wage labourer and the rest from day labourer. Total mandays employed by the rice mill labourers were 222.5 days in which 167.5 days as rice mill labourer, 22.5 days as day labourer, and 21.5 days as housemaid. The income earned by the rice mill labourers from rice parboiling activities was 87.58 percent. It was evident that, the rice mill labourers were much more diversified income earners than the farm labourers (Table 7).

Table 7. Sources and patterns of income and employment

\begin{tabular}{|l|c|c|c|c|}
\hline \multirow{2}{*}{ Items } & \multicolumn{2}{|c|}{ Farm labourer } & \multicolumn{2}{c|}{ Rice mill labourer } \\
\cline { 2 - 5 } & $\begin{array}{c}\text { Employment (Ave. } \\
\text { annual days) }\end{array}$ & Income (Taka) & $\begin{array}{c}\text { Employment (Ave. } \\
\text { annual days) }\end{array}$ & Income (Taka) \\
\hline Agricultural wage labourer & $120.45(75.62)$ & $6263.4(86.06)$ & $11.0(4.94)$ & $616(5.49)$ \\
\hline Rice parboiling & - & - & $167.5(75.29)$ & $9824.1(87.58)$ \\
\hline Day labourer & $39.47(24.38)$ & $1014.6(13.94)$ & $22.5(10.11)$ & $562.5(5.01)$ \\
\hline Housemaid & - & - & $21.5(9.66)$ & $215(1.92)$ \\
\hline Total & $159.29(100)$ & $7278(100)$ & $222.5(100)$ & $11217.6(100)$ \\
\hline
\end{tabular}

Source: Field Survey, 2010

Note: Figures in the parentheses indicate percentages

Women's contribution to overall households' income: The average total family incomes of the respondents were Tk.44952 and Tk.46128 for the farm and rice mill labourers, respectively. Respondents' contributions were 16.32 and 24.32 percent of their overall yearly family income which directly help to maintain the family livelihood (Figure 1 and Table 8). 
Table 8. Contribution of women to the overall household income

\begin{tabular}{|l|c|c|}
\hline \multicolumn{1}{|c|}{ Items } & Farm labourer & Rice mill labourer \\
\hline Total family income (Tk/yr) & 44592 & 46128 \\
\hline Respondents income (Tk/yr) & 7278 & 11217 \\
\hline Contribution (\%) & 16.32 & 24.32 \\
\hline
\end{tabular}

Patterns of expenditure: The main items of expenditures were food, clothing, housing, education, health, social expenditure, recreation and so on. Average annual expenditure of the farm labourer households was Tk.35268.96 and Tk.44334.0 per year, respectively before and after engaging as the farm labourers. Larger share of the total expenditure spent on food items (83.60 percent before and 81.58 percent after). They spent a very small proportion of their total on education and recreation (before 1.19 and 0.20 percent and after 2.49 and 0.23 percent). After food, most important items were clothing (4.20 percent before and 4.25 percent after) followed by health ( 3.78 percent before and 3.46 percent after) and housing (3.22 percent before and 3.49 percent after).

Average annual expenditure of the rice mill labourer households was Tk.32508 and Tk.46500 per year, respectively before and after engaging as the rice-parboiling labourers. Larger share of the total expenditure spent on food items (83.24 percent before and 79.79 percent after). They spent a little proportion of their total on education and recreation (before 1.11 and 0.15 percent and after $2.63 \& 0.18$ percent). After food, the most important items were clothing (4.02 percent before and 4.00 percent after) followed by housing ( 3.47 percent before and 3.85 percent after) and health (3.03 percent before and 3.38 percent after) (Table 9 ).

Table 9. Patterns of expenditure of the sample households

\begin{tabular}{|l|c|c|c|c|}
\hline \multirow{2}{*}{ Items of expenditure } & \multicolumn{4}{|c|}{ Average annual expenditure (Tk) } \\
\cline { 2 - 5 } & \multicolumn{2}{|c|}{ Farm labourer } & \multicolumn{2}{c|}{ Rice mill labourer } \\
\cline { 2 - 5 } & Before & After & Before & After \\
\hline Food & $29485.7(83.60)$ & $36168(81.58)$ & $27060(83.24)$ & $37104(79.79)$ \\
\hline Clothing & $1481.28(4.20)$ & $1884(4.25)$ & $1308(4.02)$ & $1860(4.00)$ \\
\hline Housing & $1135.8(3.22)$ & $1548(3.49)$ & $1128(3.47)$ & $1788(3.85)$ \\
\hline Education & $418.2(1.19)$ & $1104(2.49)$ & $360(1.11)$ & $1224(2.63)$ \\
\hline Health & $1332(3.78)$ & $1536(3.46)$ & $984(3.03)$ & $1572(3.38)$ \\
\hline Recreation & $72(0.20)$ & $102(0.23)$ & $48(0.15)$ & $84(0.18)$ \\
\hline Others & $1344(3.81)$ & $1992(4.49)$ & $1620(4.98)$ & $2868(6.17)$ \\
\hline Total & $35268.96(100)$ & $44334.0(100)$ & $32508.0(100)$ & $46500.0(100)$ \\
\hline
\end{tabular}

Source: Field Survey, 2010

Note: Figures in the parentheses indicate percentages

Food consumption information of the households: The major food items for meeting daily consumption requirements were rice, wheat/flour, pulses, fish and vegetables. They rarely consume meat and fruits due to lack of sufficient money. Most of the consumption requirements were met by consuming rice and its consumption was increased by both the farm and rice mill labourers over time. Sometimes, consumption of some items, such as, pulses and meat were decreased and that might be due to the high prices of those commodities. The overall analysis indicated some sort of significant changes in the level of poverty of the sample households. The women labourers incomes somehow contribute to the overall family income and it helps in reducing poverty (Table 10).

\section{Factors influencing the level of family income}

Age of the respondents $\left(\mathbf{X}_{1}\right)$ : It is evident from the results presented in Table 11 that the coefficient of age of the respondents was positive but statistically insignificant for farm labourer and significant for rice mill labourer. The result implied that 1 percent increase in the age of the respondent, keeping other factors constant, would result in an increase in average annual family income by 0.108 percent for farm labourer and 0.146 percent for rice mill labourer, respectively. 
Table 10. Food consumption information of the respondents' family

\begin{tabular}{|c|c|c|c|c|c|c|c|c|}
\hline \multirow{3}{*}{ Food items } & \multicolumn{4}{|c|}{ Farm labourer } & \multicolumn{4}{|c|}{ Rice mill labourer } \\
\hline & \multicolumn{2}{|c|}{ Before } & \multicolumn{2}{|c|}{ After } & \multicolumn{2}{|c|}{ Before } & \multicolumn{2}{|c|}{ After } \\
\hline & $\begin{array}{l}\text { No. of } \\
\text { times }\end{array}$ & $\begin{array}{c}\text { Quantity } \\
\text { (kg) }\end{array}$ & $\begin{array}{l}\text { No. of } \\
\text { times }\end{array}$ & $\begin{array}{l}\text { Quantity } \\
\text { (kg) }\end{array}$ & $\begin{array}{l}\text { No. of } \\
\text { times }\end{array}$ & $\begin{array}{l}\text { Quantity } \\
\text { (kg) }\end{array}$ & $\begin{array}{l}\text { No. of } \\
\text { times }\end{array}$ & $\begin{array}{l}\text { Quantity } \\
\text { (kg) }\end{array}$ \\
\hline Rice $^{*}$ & 2.86 & 2.14 & 3.00 & 2.25 & 2.83 & 1.69 & 3.00 & 2.33 \\
\hline Wheat $^{*}$ & 0.018 & 0.018 & - & - & 0.13 & 0.07 & - & - \\
\hline Pulses $^{\text {*x }}$ & 2.25 & 0.45 & 2.21 & 0.477 & 1.62 & 1.16 & 1.78 & 0.36 \\
\hline Fish $^{\text {** }}$ & 1.98 & 0.70 & 2.28 & 0.88 & 2.09 & 0.78 & 2.23 & 0.95 \\
\hline Meat & 0.45 & 0.18 & 0.66 & 0.25 & 1.23 & 0.57 & 1.38 & 0.63 \\
\hline Vegetables $^{*}$ & 3.70 & 2.05 & 3.66 & 2.08 & 3.93 & 1.71 & 4.13 & 2.36 \\
\hline Fruits $^{* *}$ & 0.29 & 0.07 & 0.39 & 0.11 & 0.18 & 0.05 & 0.42 & 0.15 \\
\hline
\end{tabular}

Source: Field Survey, 2010

Note: ${ }^{*}$ No. of times per day; ${ }^{\star \star}$ No. of times per week; ${ }^{\star \star \star}$ No. of times per month

Family size of the respondents $\left(\mathbf{X}_{2}\right)$ : The coefficient of respondents' family size was positive and statistically significant at 1 percent level of significance for the farm labourer and insignificant for the rice mill labourer. The result implied that 1 percent increase in the number of family members of the respondent, keeping other factors constant, would result an increase in average annual income by 0.334 percent for farm labourer and 0.937 percent for the rice mill labourer households (Table 11).

Land holding of the respondent $\left(\mathrm{X}_{3}\right)$ : The coefficient of land holding of the respondents was positive and statistically significant for both the farm and rice mill labourers. The result implied that 1 percent increase in the land holding of the respondent, keeping other factors constant, would result an increase in average annual income by 0.189 percent and 0.195 percent for the farm and rice mill labourer, respectively (Table 11).

Table 11. Estimated coefficients and related statistics of the log-linear regression model

\begin{tabular}{|c|c|c|}
\hline \multirow[b]{2}{*}{ Explanatory variables } & \multicolumn{2}{|c|}{ Estimated coefficients } \\
\hline & Farm labourer & Rice mill labourer \\
\hline Constant & $7.382^{* \pi x}(9.177)$ & $0.947(0.67)$ \\
\hline Age $\left(X_{1}\right)$ & $0.108(1.075)$ & $0.146^{*}(1.859)$ \\
\hline Family Size $\left(X_{2}\right)$ & $0.334^{* * \star}(2.686)$ & $0.078(0.937)$ \\
\hline Land holding $\left(\mathrm{X}_{3}\right)$ & $0.189^{* x}(1.931)$ & $0.195^{2 \times x}(2.501)$ \\
\hline Earning members $\left(\mathrm{X}_{4}\right)$ & $0.356^{\text {*x* }}(2.909)$ & $0.143^{*}(1.867)$ \\
\hline Respondents' income $\left(X_{5}\right)$ & $0.258^{* * \star}(2.628)$ & $0.856^{* * *}(11.69)$ \\
\hline $\mathrm{R}^{2}$ & 0.558 & 0.761 \\
\hline Adjusted $\mathrm{R}^{2}$ & 0.513 & 0.734 \\
\hline F-value & $12.607^{* * i}$ & $27.429^{* \star \star}$ \\
\hline
\end{tabular}

Note: Figures in the parentheses indicate t-value

*** Significant at 1\% level; ** Significant at 5\% level; * Significant at $10 \%$ level

Source: Field Survey, 2010

Number of earning members $\left(\mathbf{X}_{4}\right)$ : The coefficient of the number of earning members was positive and statistically significant for both the farm and rice mill labourers. The result implied that 1 percent increase in the number of earning members, keeping other factors constant, would result an increase in average annual income by 0.356 percent and 0.143 percent, respectively for the farm and rice mill labourer (Table 11).

Respondent's income $\left(\mathbf{X}_{5}\right)$ : The coefficient of respondent's income was positive and statistically significant for both the farm and rice mill labourer. The result implied that 1 percent increase in respondent's income, keeping other factors constant, would result an increase in average annual income by 0.258 percent and 0.856 percent, respectively for the farm and rice mill labourer (Table 11). 
Coefficients of multiple determinations $\left(\mathbf{R}^{2}\right)$ : The coefficients of multiple determinations, $R^{2}$ was 0.558 for farm and 0.761 for rice mill labourer, respectively and implied that 56 percent and 76 percent of the variations in average annual income could be explained by the explanatory variables included in the model for farm and rice mill labourer, respectively (Table 11).

F-value: The measure of the overall fitness of the estimated regression, F-values was highly significant at 1 percent level, for both the farm and rice mill labourer, implied that inclusion of the variables were important for explaining the variation in average annual income (Table 11).

Problems and constraints: The problems of farm and rice parboiling activities were identified based on opinion of the related parties. Nevertheless, the most common and crucial problems of related respondents are discussed below:

Table 12. Major problems faced by the labourers in the study area

\begin{tabular}{|l|c|c|c|c|}
\hline \multirow{2}{*}{ Nature of problems } & \multicolumn{2}{|c|}{ Farm labourer } & \multicolumn{2}{c|}{ Rice mill labourer } \\
\cline { 2 - 5 } & Number & Percent & Number & Percent \\
\hline Seasonal work & 50 & 83.33 & 52 & 86.67 \\
\hline Tendency to have suffering from body ache & 38 & 63.33 & 40 & 66.67 \\
\hline Sudden sack from job & 24 & 40.00 & 20 & 33.33 \\
\hline Low level of salary than male labourers & 15 & 25.00 & 21 & 35.00 \\
\hline
\end{tabular}

Source: Field Survey, 2010

The sampled labourers reported that only two rice yielding seasons and post harvest processing periods were the main working season of the farm and rice mill labourers. Eighty three percent farm labourer and 86 percent rice mill labourer faced this situation. Sixty three percent of the farm labourer and 66 percent of the rice mill labourer had suffered from body ache. Farm and rice mill activities are tedious jobs for women; as a result, sometimes they suffered from intense pain and for that, they have spent quite more for medicine to relieve from pain. In the study area 40 percent farm and 33 percent rice mill labourers complained that, the employers might sack themselves without noticing them. Twenty five percent of the farm and 35 percent rice mill labourers have reported that men work more in a particular time and paid better than the female labourers.

\section{Conclusion and Recommendation}

In Bangladesh, women constitute nearly half of the total population of the country. Women played an important role in farm activities especially in post-harvest operations, homestead gardening, livestock and poultry rearing. Economic pressure is forcing the rural women to break down their traditional roles as housewives into farm and rice mill activities. The present study revealed that the contribution of female labor in different activities as well as in total family income is substantial.

Women contributed a small amount but a significant proportion of their total family income. Poverty alleviation can hardly be achieved unless the women are directly being involved in income generating activities. The socioeconomic status of the women in farm and rice mill labourers should be improved through their direct participation in income generating activities. The educational status, land holding and other household assets position were improved due to the women's contribution to overall family income. Patterns of family expenditure remained same before and after the women involvement in farm and rice mill works but increased over time that indicated some significant changes in the level of poverty of the households. Age of the respondents, family size, land holding, number of earning members and respondents' income contributed significantly to the variability of income and employment. Farm and rice parboiling activities are mostly of seasonal; the government should undertake appropriate policy for income generating activities of the rural poor, especially for rural women throughout the year. However, training and credit facilities should be offered to the rural women to improve and utilize their skill and efficiency for poverty alleviation in rural areas. 


\section{Rahman and Hasan}

\section{References}

Akhter, S., Banu, K., Sarker, S., Joarder, N.J. and Shaha, R.R. 1995. Women in farming and income earning: Study of a Gazipur village. Journal of Rural Development, Department of Economics, Shajalal University of Science and Technology, Sylhet, Bangladesh.

BBS. 2007. Statistics Year Book of Bangladesh. Bangladesh Bureau of Statistics, Ministry of Planning, Government of the People's Republic of Bangladesh, Dhaka, Bangladesh.

BBS. 2008. Statistics Year Book of Bangladesh. Bangladesh Bureau of Statistics, Ministry of Planning, Government of the People's Republic of Bangladesh, Dhaka, Bangladesh.

Begum, Mahfuza. 2005. A Study on Women Employment in Farms and Rice-Parboiling Mills in Some Selected Areas of Dinajpur District. An unpublished thesis submitted to the Department of Agricultural Economics, Bangladesh Agricultural University, Mymensingh.

Gujarati, D.N. 1998. Basic Econometrics, $3^{\text {rd }}$ edn. McGraw-Hill Inc. London.

Harris, B. 1978. Rice processing project in Bangladesh: an appraisal of a decade of proposal. Bangladesh Journal of Agricultural Economics, 1(2): 24-52.

Haq, J. 1981. Employment generation, cottage industries and women: role and strategy. Bangladesh Journal of Political Economy (Bangladesh). Vol. 5(1): p. 101-110.

Salauddin, K. 1980. Women and technology: Impact of technological change in agriculture on rural women of Bangladesh Dhaka (Bangladesh). 